\title{
Probable cervical vertebra of an extinct Ice Age elkmoose dredged from the inner continental shelf of central New Jersey, USA
}

\author{
Martin A. Becker ${ }^{1}$, John A. Chamberlain JR. ${ }^{2^{*}}$, And Rebecca B. Chamberlain ${ }^{3}$ \\ 1. Department of Environmental Science, William Paterson University, Wayne, New Jersey 07470, USA \\ 2. Department of Geology, Brooklyn College, Brooklyn, New York 11210, USA, and Doctoral Program in \\ Earth and Environmental Sciences, CUNY Graduate Center, New York, New York 10016, USA \\ 3. Department of Biology, College of Staten Island, Staten Island, New York 10314, USA \\ *Corresponding author $<$ johnc@brooklyn.cuny.edu>
}

Date received 29 September 2009 gate accepted 11 January 2010

\begin{abstract}
Commercial shell-fishing activities off the central New Jersey coast recovered a single cervical vertebra probably belonging to the extinct elkmoose, Alces scotti. The specimen was discovered $40 \mathrm{~km}$ southeast of Manasquan Inlet in $40-45 \mathrm{~m}$ of water at approximate latitude $39^{\circ} 45^{\prime} \mathrm{N}$ and longitude $73^{\circ} 30^{\prime} \mathrm{W}$. Radiocarbon dating yielded an age of $23530 \pm 170$ years BP for the vertebra. This date is consistent with the known age range of this species and predates the migration of the modern moose Alces alces into northeastern North America from western North America and Eurasia. The discovery of Pleistocene terrestrial mammal fossils, such as this bone, on the submerged northeastern continental shelf reflects periglacial habitat shifts. These habitat shifts are the product of glacioeustatically controlled shoreline migration associated with the Wisconsinan glacial maximum. We interpret this vertebra as probably deriving from an animal living in a tundra or taiga setting at a distance of 100 to $200 \mathrm{~km}$ from the southern edge of the Laurentide ice sheet.
\end{abstract}

\section{RÉSUMÉ}

Les activités de pêche commerciale aux crustacés et aux mollusques au large de la côte du New Jersey ont donné lieu à la découverte d'une vertèbre cervicale unique, qui appartiendrait vraisemblablement à une espèce d'élan depuis longtemps disparue, Alces scotti. Le spécimen a été découvert dans l'eau à $40 \mathrm{~km}$ au sud-est du passage de Manasquan, à une profondeur d'environ 40 à $45 \mathrm{~m}$, approximativement à la latitude $39^{\circ} 45^{\prime}$ nord et à la longitude $73^{\circ} 30^{\prime}$ ouest. La datation par le carbone 14 a établi l'âge de la vertèbre, qui remonterait à 23530 ans $\mathrm{BP}$ (avant le présent), à 170 ans près. Cet âge correspond à la période connue de l'existence de cette espèce, laquelle a précédé l'arrivée de l'élan moderne Alces alces au nord-est de l'Amérique du Nord, en provenance de l'ouest du continent nord-américain et de l'Eurasie. La découverte de fossiles de mammifères du Pléistocène, comme cette vertèbre, sur le plateau continental submergé du nord-est rend compte de l'évolution périglaciaire des habitats. Ces mutations d'habitat sont le résultat d'une migration côtière déterminée par le contexte glacio-eustatique, caractéristique de la période glaciaire maximale $\mathrm{du}$ Wisconsin. L'interprétation que nous faisons de cette vertèbre nous porte à croire qu'elle provient probablement d'un animal qui vivait dans la toundra ou la taïga, à une distance d'environ 100 à $200 \mathrm{~km}$ de la bordure sud de la plaque glaciaire des Laurentides.

[Traduit par la redaction]

\section{INTRODUCTION}

For over three-quarters of a century, commercial shell fishing operations along the northeastern continental shelf of the United States have infrequently recovered fossils (e.g., Dall 1925; Uchupi 1964; Wigley 1966; Stanley et al. 1967; Whitmore et al. 1967; Gallagher 1989; McDonald and Ray 1990, 1993). These fishing operations characteristically target Atlantic surf clams, Spisula solidissima, and deep-sea scallops,
Placopecten magellanicus, through the use of various seafloor dredging techniques. Accidental by-catch commonly includes anthropogenic materials and, in rare instances, fossils. Such fortuitous fossil discoveries have been made down to a depth of about $120 \mathrm{~m}$, which reflects the position of the Last Glacial Maximum paleoshoreline in the northeastern Atlantic during the Pleistocene (Whitmore et al. 1967). Remains of both marine and terrestrial mammals have been recovered. Marine mammal examples include bones from the genera Phoca 


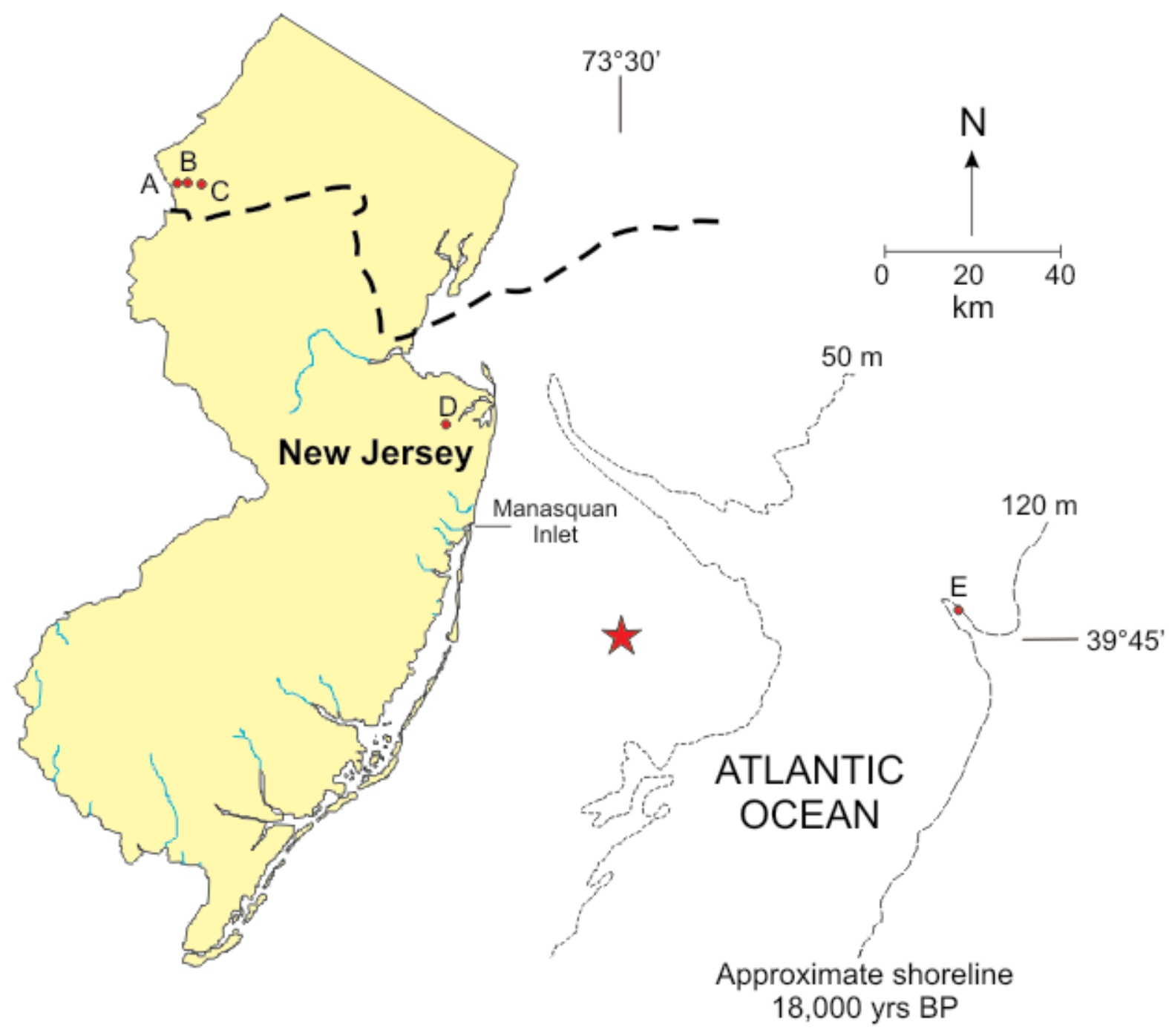

Fig. 1. Location map identifying Alces scotti discovery sites in New Jersey. The star shows the approximate location of the discovery site for the specimen described herein. Recovery sites for other Alces scotti specimens are: (A) Columbia, Warren County, New Jersey; (B) Knowlton Township, Warren County, New Jersey; (C) Mount Hermon, Warren County, New Jersey; (D) Big Brook, Monmouth County, New Jersey; and (E) Hudson Canyon at a depth of $160 \mathrm{~m}$. Thick dashed line is the southern limit of Wisconsin Glaciation about 18000 years BP. Dotted lines show the modern $50 \mathrm{~m}$ and $120 \mathrm{~m}$ isobaths. Map modified from Gallagher et al. (1989).

and Odobenus, as well as various cetaceans; while terrestrial mammal examples include bones from the genera Mammut, Mammuthus, Rangifer, Tapirus, Cervalces (= Alces), Symbos, Bison, and Megalonyx (e.g., Dall 1925; Uchupi 1964; Wigley 1966; Stanley et al. 1967; Whitmore et al. 1967; Parris 1983; Gallagher et al. 1989; McDonald and Ray 1990, 1993).

In this report, we describe and identify a cervical vertebra recently recovered by commercial shell fishing operations 40 $\mathrm{km}$ southeast of Manasquan Inlet, New Jersey. The vertebra was recovered along with three cetacean vertebrae at a depth of $40-45 \mathrm{~m}$ at approximate latitude $39^{\circ} 45^{\prime}$ and longitude $73^{\circ}$ $30^{\prime}$ (Fig. 1). Anatomical comparisons to skeletons held by the New Jersey State Museum (NJSM), the American Museum of Natural History (AMNH), the Academy of Natural Sciences of
Philadelphia (ANSP), and the Yale Peabody Museum (YPM), suggest that the progenitor of the vertebra is most probably the extinct Ice Age cervid commonly known as the elkmoose or stagmoose.

\section{SYSTEMATIC STATUS OF THE ELKMOOSE (ALCES OR CERVALCES?)}

The genus Cervalces was created by Scott (1885) to include a newly discovered elkmoose skeleton in Quaternary sediments from New Jersey, as well as elkmoose fossils from the Big Bone Lick site in Kentucky named Cervus americanus by Harlan (1825). Lydekker (1898) questioned Scott's origi- 
nal designation of the New Jersey and Kentucky material as Cervalces americanus due to its similarity to the genus Alces, and noted that the name Cervus americanus was preoccupied. Lydekker (1898) therefore placed the species in the genus Alces and renamed it scotti. Since that time, some researchers have chosen to maintain the generic name Cervalces and have referred to this species as Cervalces scotti (e.g., Bensley 1913; Hay 1913; Frick 1937; Azzaroli 1981), while others have followed Lydekker (e.g., Kahlke 1990). These divergent views reflect the fact that the taxonomy of fossil alcines has been in considerable flux for decades due to the paucity of taxonomically useful fossil material.

Churcher and Pinsof (1987) reviewed the taxonomic status and occurrence of the genus Cervalces and concluded that known specimens fit into two species, Cervalces scotti and Cervalces latifrons. According to Churcher and Pinsof (1987), distinctions between the two species are primarily based on antler palmation characteristics. Cervalces latifrons antlers are long beamed and palmate while those of Cervalces scotti are short beamed and subdivided with relatively more pronounced tines. In addition, Churcher and Pinsof (1987) recognized the existence of a cline in antler size in Cervalces scotti in which antlers become progressively smaller southeastward across North America.

The problem of alcine taxonomy and the status of Cervalces were also considered by Kahlke (1990). He viewed the fact that that nearly every fossil alcine species has been placed in its own genus or subgenus to be indicative of an incomplete systematic data base. Kahlke argued that with new fossil discoveries in the late Twentieth Century it has become increasingly evident that transitions between successive species can be recognized, but it has become more difficult to segregate genera. He therefore placed all moose-like forms in a single genus, Alces. In this paper, we follow Kahlke (1990) and refer to Cervalces as Alces, and thus use Alces scotti (Lydekker, 1898) as the preferred name for the specimen described herein.

\section{DESCRIPTION}

The Manasquan vertebra described here has been deposited in the collections of the New Jersey State Museum and has been assigned the catalogue number NJSM 20004 (Fig. 2). The $596 \mathrm{~g}$ vertebra has limonitic surface staining and shows significant post-mortem abrasion and degradation. It is missing most of the neural spine (Fig. 2a) and much of the left posterior zygapophysis (Fig. 2c). Additionally, part of the right pleurapophysis and bone directly adjacent to the transverse foramen are missing (Fig. 2e). The ventral part of the anterior centrum is also missing, but the outline of its periphery can still be seen on the broken bone surface (white arrows in Fig. 2d). Small encrusting bryozoans are scattered across portions of the vertebra's surface, particularly along the neural canal and parts of the zygapophyses and pleurapophyses. We interpret these observations to indicate that the specimen was exposed on the sea floor for some time prior to its recovery in the clam dredge.

\section{AGE OF SPECIMEN}

A small core having a total weight of $12.6 \mathrm{~g}$ was drilled from the posterior centrum for use in radiocarbon dating of the specimen. This site was selected for sample removal because it does not destroy the overall shape of the vertebra and because no epizoans were attached to the bone surface there. After removal, the bone sample was thoroughly cleaned by repeated washing in distilled water under ultrasound to remove dirt and foreign material. The sample was then crushed to fragments of about $1 \mathrm{~mm}$ across and reacted with 1N HCL under vacuum to dissolve apatite and other minerals. The insoluble residue remaining after mineral dissolution was filtered and washed. The precipitate was then boiled for eight hours in slightly acidic $(\mathrm{pH}=3-4)$ distilled water to dissolve any collagen present. The resulting broth was filtered through fiberglass and the filtrate was evaporated to dryness to recover collagen. The recovered bone collagen was combusted and the carbon dioxide produced was analyzed by accelerator mass spectrometry. The result was a radiocarbon age of $23530 \pm 170$ years BP. This age is ${ }^{13} \mathrm{C}$ corrected and is based on the Libby half life of 5570 years for ${ }^{14} \mathrm{C}$ and is referenced to the year $\mathrm{AD} 1950$. The error is 1 sample standard deviation as judged from the analytical data. The analysis was performed by Geochron Laboratories, Cambridge, Massachusetts.

\section{IDENTIFICATION}

We use bone morphology and data from the late Pleistocene and Holocene fossil record of New Jersey to identify the progenitor of the Manasquan vertebra. Our approach is to determine the most likely: (1) vertebrate group from which the specimen derives; (2) genus and species of the specimen; and (3) location in the vertebral column of the specimen.

\section{Which Vertebrate Group?}

The size, shape, and radiocarbon age of the Manasquan bone limit the range of possible vertebrates from which it could derive. These factors, together with its discovery location, suggest very strongly that it is a vertebra deriving from a large animal living on or near the now submerged part of the continental shelf at about the time of the last glacial maximum in North America. The recovery location and probable habitat place this large animal within 100-200 km of the southern terminus of the Laurentide ice sheet as mapped by Gallagher et al. (1989).

The extreme boreal conditions in which the progenitor of the Manasquan vertebra lived exclude reptiles and amphibians as the source of the bone. Fish have simple cylindrical or hourglass-shaped vertebrae lacking most of the morphological features of the Manasquan bone, and are not therefore the source of the specimen. The largest birds inhabiting such regions today - for example, eagles, auks, and geese - have vertebrae that are a small fraction of the size of the Manasquan 

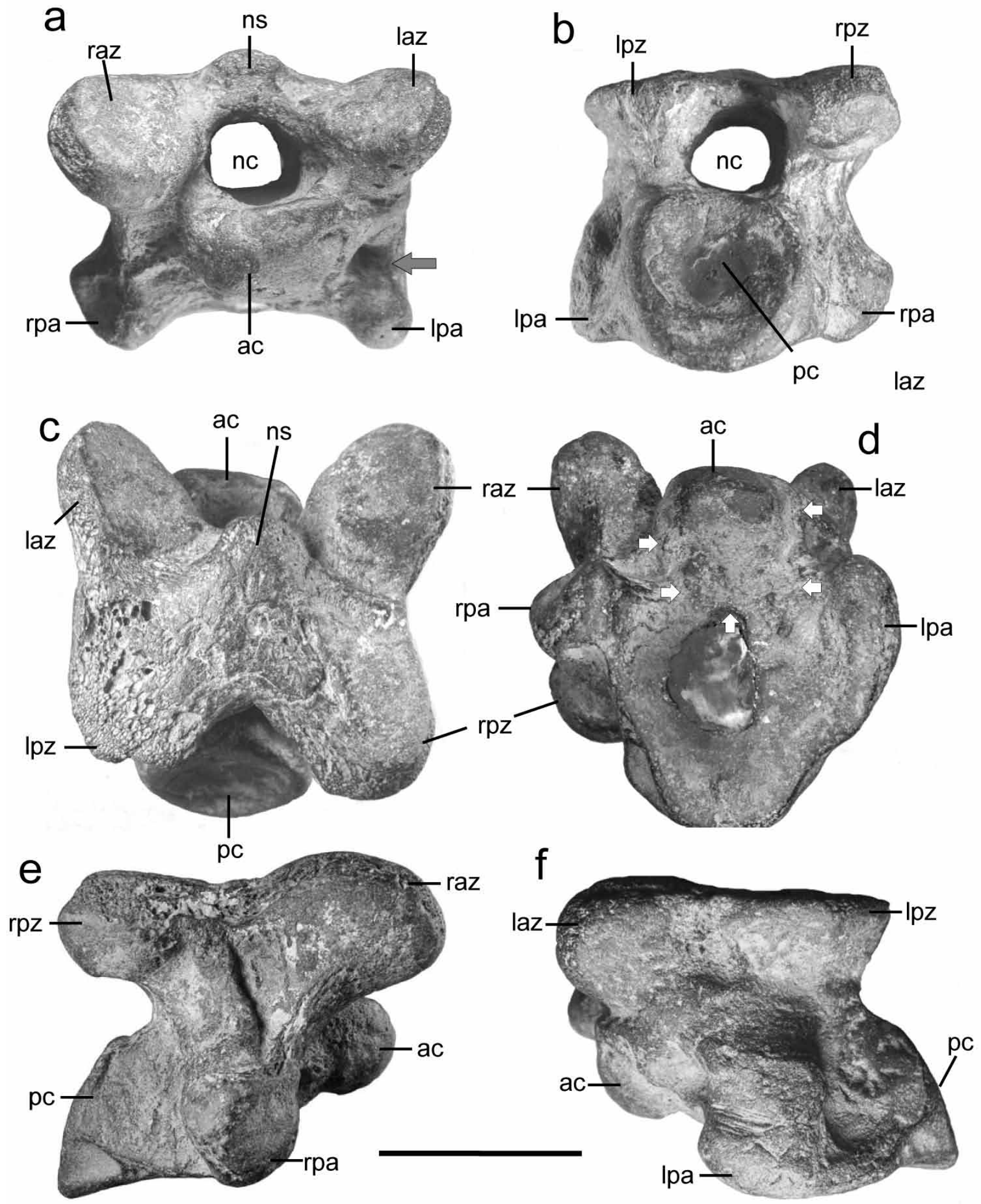

Fig. 2. Bone (NJSM 20004) described in this report. Scale bar $=5 \mathrm{~cm}$ in all figures. (a) Anterior view; arrow points to left transverse foramen. (b) Posterior view. (c) Dorsal view. (d) Ventral view; white arrows indicate the periphery of the anterior centrum. (e) Right lateral view. (f) Left lateral view. Abbreviations used in figures: ac, anterior centrum; laz, left anterior zygapophysis; lpa, left pleurapophysis; lpz, left posterior zygapophysis; nc, neural canal; ns, neural spine; pc, posterior centrum; raz, right anterior zygapophysis; rpa, right pleurapophysis; rpz, right posterior zygapophysis. 
bone. Thus, paleoclimate and vertebra size and shape exclude all vertebrate groups but mammals as the source of the bone.

Although the specimen has undergone significant bone loss, it is sufficiently pristine to show that the pleurapophysis and neural crest do not contain articulations for ribs or pelvic bones. Thus, it is not a thoracic or pelvic vertebra, and it is too morphologically complex to be a caudal vertebra. Based on these considerations, we interpret the Manasquan specimen to represent a mammalian cervical vertebra $(\mathrm{CV})$. The boxlike shape evident in Fig. 2 excludes the atlas (CV1) and axis (CV2) vertebrae as they have axially flattened and prominently axially keeled shapes that function to provide strong articulation between the skull and neck. We infer from this that our specimen is one of the more posterior neck bones of a large, periglacial mammal.

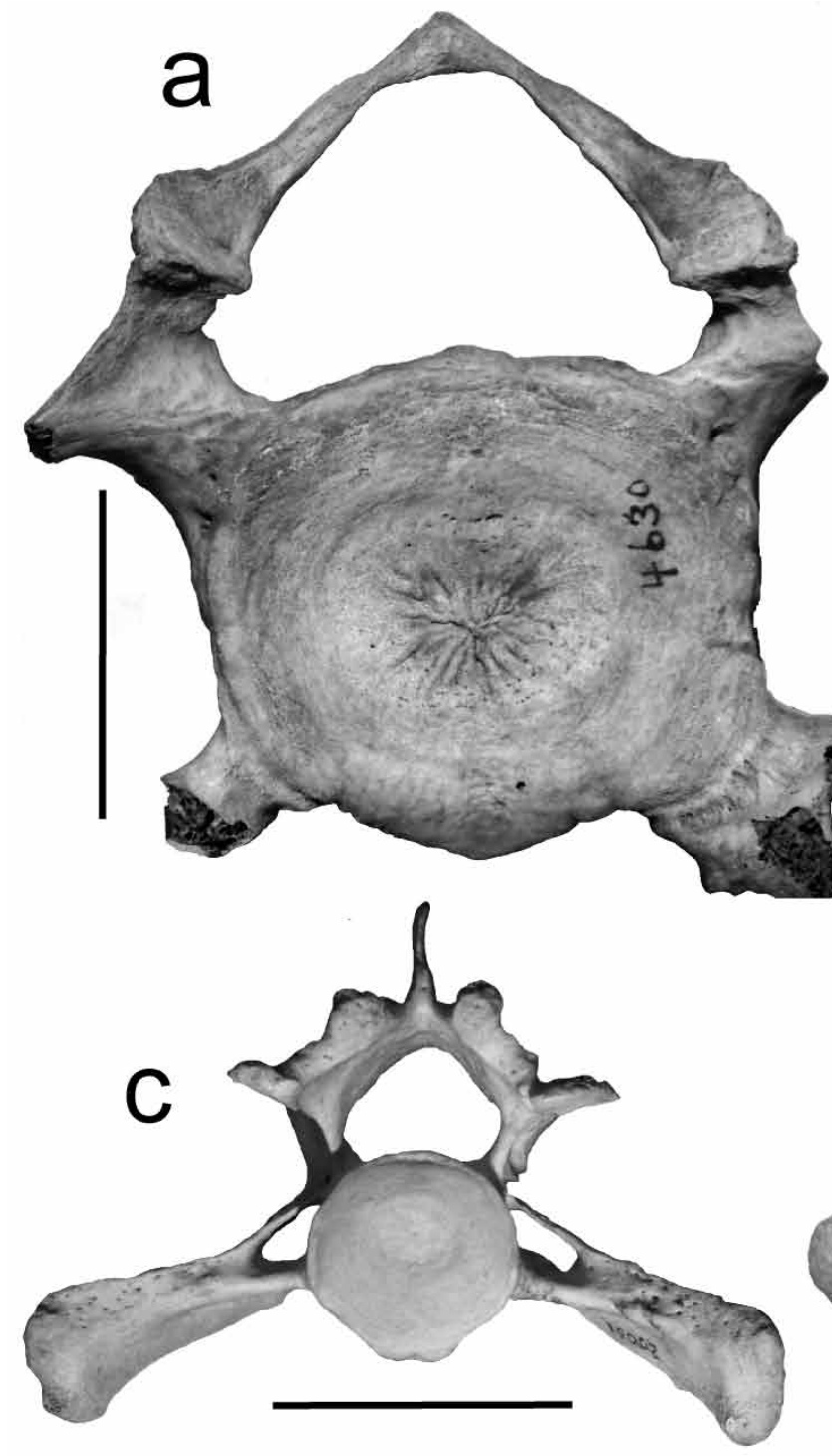

\section{Which Mammal Group?}

We first consider marine mammals. Figure 3 a shows a narwhal cervical vertebra. It has a large, triangular neural canal, unlike the smaller, circular neural canal of the Manasquan bone evident in Fig. 2. In addition, the narwhal vertebra lacks the prominent zygapophyses of the Manasquan bone. Other cetaceans have similarly structured cervical vertebrae. These disparities indicate that the Manasquan bone is not that of a cetacean. A representative example of the cervical bones typical of each of the three families of pinnipeds is also shown in Fig. 3 (phocids in 3b, otariids in 3c, and odobenids in 3d). As illustrated in Fig. 3, pinnipeds have cervical vertebrae differing from the Manasquan bone in three essential features. Pinniped cervical vertebrae have large triangular neural canals; their
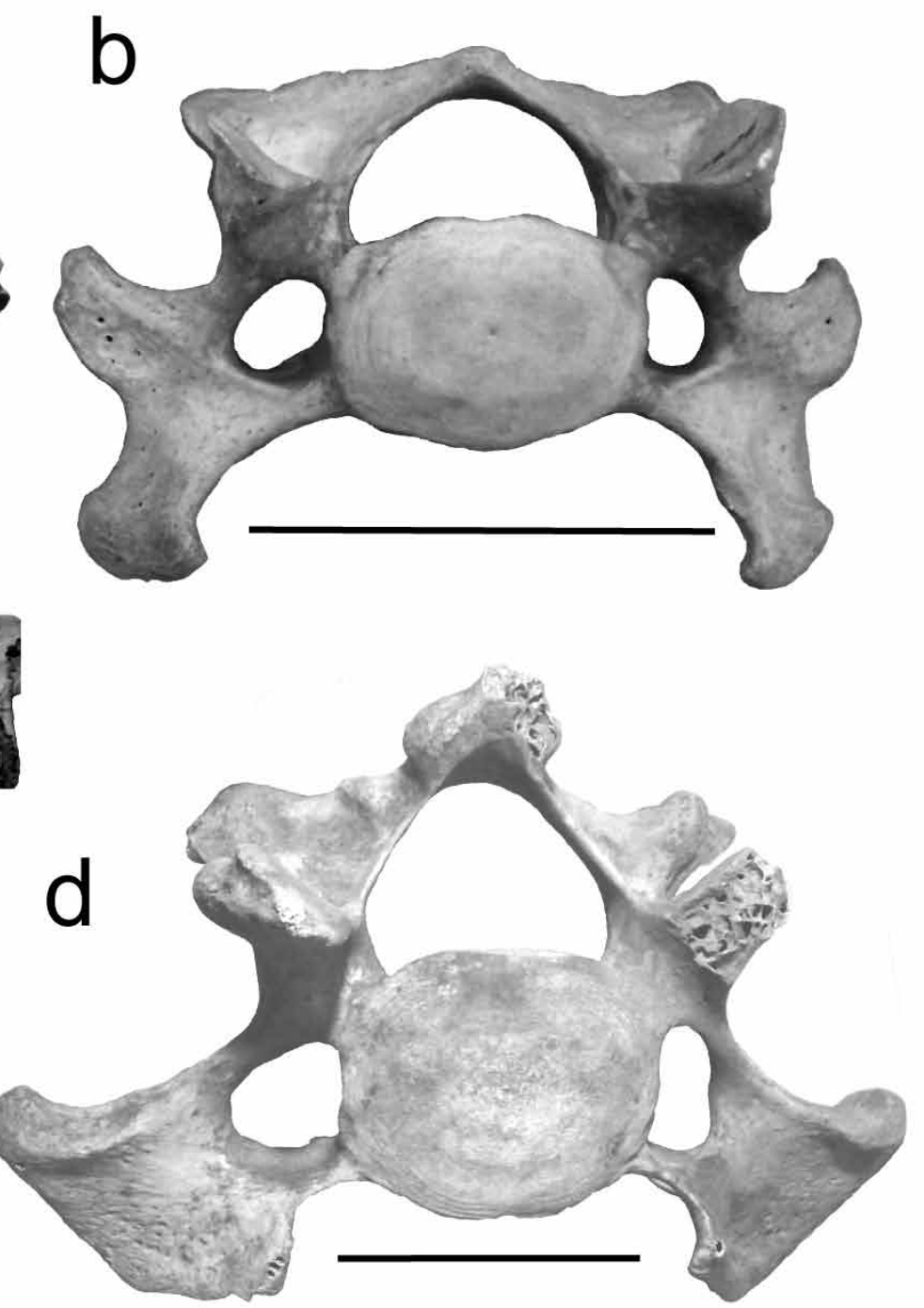

Fig. 3. Cervical vertebrae of four marine mammals. Scale bars $=5 \mathrm{~cm}$. (a) Narwhal (Monodon monoceros); anterior view (ANSP mammology 4630). (b) Bearded seal (Erignathus barbatus); anterior view (ANSP mammology 20606). (c) Sea lion (Zalophus californianus); anterior view (ANSP mammology 20051). (d) Walrus (Odobenus rosmarus); anterior view (ANSP mammology 2938). 
zygapophyses are smaller and less pronounced than for the Manasquan vertebra; and their centra are elongated laterally rather than dorsoventrally. We conclude from these comparisons that the specimen in question is unlikely to have derived from a marine mammal.

The Late Pleistocene and early Holocene fossil record of northeastern North America provides a relatively limited range of possible terrestrial mammalian candidates for the
Manasquan specimen: mastodon (Mammut americanum); wooly mammoth (Mammuthus primigenius); bears, particularly polar bear (Ursus maritimus); large periglacial bovids, especially musk oxen (Bootherium bombifrons; Ovibos moschata) and ice age bison(Bison latifrons); and larger periglacial cervids (caribou, elkmoose, and moose).

Both Mammut and Mammuthus have axially compressed cervical vertebrae typical of proboscideans, rather than the
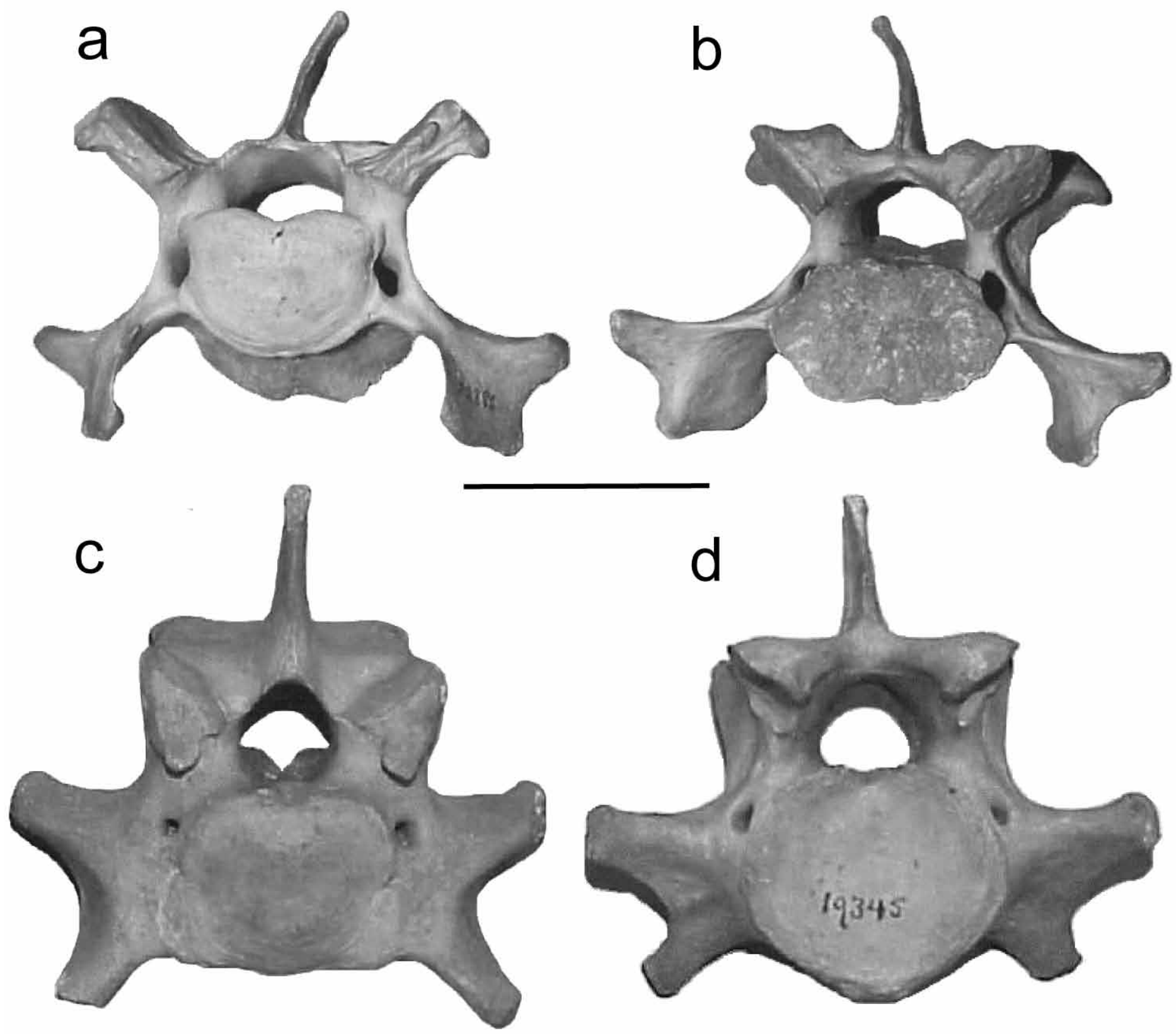

Fig. 4. Fourth cervical vertebrae of two large boreal terrestrial mammals. Scale bars = $5 \mathrm{~cm}$. (a-b) Polar bear (Ursus maritimus); anterior view (a) and posterior view (b) (AMNH2285). (c-d) Musk oxen (Ovibos moschata); anterior view (c) and posterior view (d) (AMNH19345). 
box-like morphology of our specimen, and can thus be excluded. Additionally, in all but very young juveniles, the size of the cervical vertebrae in Mammut and Mammuthus are considerably larger than our specimen. Figures $4 \mathrm{a}$ and $4 \mathrm{~b}$ show the fourth $\mathrm{CV}$ of a modern polar bear. It is considerably more gracile than our specimen, and has centra that are laterally elongated. This differs from the Manasquan vertebra in which the centra are dorsoventrally elongated (Figs. 2b, 2d). The other polar bear neck vertebrae are similarly structured, as are those of the other North American boreal bears, i.e., the arctic brown bear (Ursus arctos) and the grizzly bear (Ursus horribilis). These obvious disparities exclude bears as the source of our specimen. Figures. $4 \mathrm{c}$ and $4 \mathrm{~d}$ show the fourth $\mathrm{CV}$ of a modern musk ox (Ovibos moschata). Like the Manasquan vertebra, the musk oxen specimen is robustly built and has a box-like overall shape. However, its zygapophyses are smaller and do not flare laterally to the extent seen in the Manasquan specimen. In addition, the musk oxen vertebra has centra that are laterally elongated. These differences eliminate this musk oxen species as the source of our bone. Because Bison latifrons has cervical vertebrae similar to those of Ovibos moschata (as do most large bovids), this species is also excluded. Elimination of these other mammalian candidates based on cervical-vertebra morphology indicates that the most likely source for the Manasquan specimen is a large cervid.

\section{Which Cervid?}

Among fossil cervids, features of the skull and antlers are most often used as criteria to distinguish fossil taxa. Such attributes are clearly not applicable in the present case. Instead, our study of the Manasquan specimen relies on morphological comparisons to cervical vertebrae of four large North American cervids: Alces alces (moose), Alces scotti (elkmoose), Rangifer tarandus (caribou), and Cervus canadensis (elk). Alces alces, Alces scotti, and Rangifer tarandus are boreal cervids known from the North American fossil record and thus are possible progenitors of the Manasquan specimen. Cervus canadensis makes a good comparative outgroup against which to evaluate the other species, and is included in our study for that reason. On paleoenvironmental grounds, however, Cervus canadensis is unlikely to be the source of the Manasquan vertebra in view of its modern non-boreal habitat preference. We exclude Alces latifrons and other large Eurasian boreal cervids (e.g., Megaloceros giganteus) from consideration because they are unknown in the New Jersey fossil record.

The cervid specimens we examined are listed in Table 1. For each specimen we measured CV3 through CV6. We excluded CV1, CV2 on morphological grounds as noted above. We also excluded the posteriormost cervical vertebra $(\mathrm{C} 7)$ because, in the cervids we examined, $\mathrm{C} 7$ is transitional to the thoracic vertebrae. It is foreshortened axially, has prominent keels, and lacks the box shape of the Manasquan bone. Parameter measurement was done from digital images of single bones using Bersoft Image Measurement ${ }^{\circledR}$ software. Not all parameters could be measured in all bones examined due to break-related bone loss. Also, in the case of the NJSM elkmoose specimen (see Table 1), we were working with a restored, articulated skeleton so that parameters deriving from articulating bone surfaces, e.g., anterior and posterior centrum diameters, were difficult or impossible to obtain. Because of the small number of specimens sampled, rigorous statistical testing is not possible. All specimens we measured are large enough to have derived from adult animals, so we consider possible ontogenetic variation in bone morphology among sub-adult animals to be inconsequential to our analysis. Also, there is no known gender component to morphology among cervid cervical bones. Thus, differences discovered, if sufficiently robust, should have taxonomic significance.

We focus here on the shape of cervid cervical vertebrae in dorsal view. Vertebral shape is defined as the ratio of vertebral length to vertebral width (see Fig. 5). Defining length and width as shown in Fig. 5 allows us to exclude the size and flaring of the zygapophyses in our consideration of bone shape.

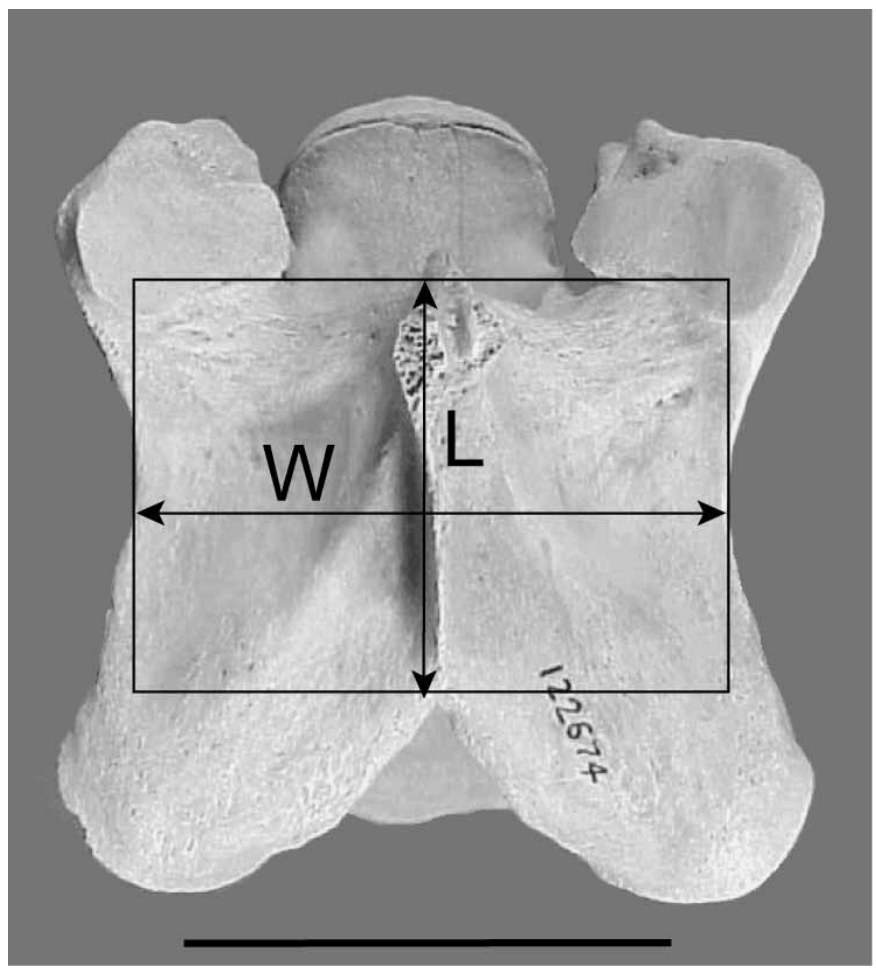

Fig. 5. Definition of some morphological parameters used in this study. Scale bar $=5 \mathrm{~cm}$. Dorsal view of CV3 of Alces alces; anterior at top (AMNH122674). $\mathrm{L}=$ bone length in dorsal view. $L$ is defined as the length of the line drawn parallel to the body axis between the anterior margin of the bone in dorsal view (visible between the anterior zygapophysal articulations) and a line perpendicular to the body axis drawn through the point from which the posterior zygapophyses diverge. $\mathrm{W}=$ bone width in dorsal view. W is defined as the length of the line drawn perpendicular to the body axis at the narrowest part of the bone and extending from one edge of the bone to the other. 


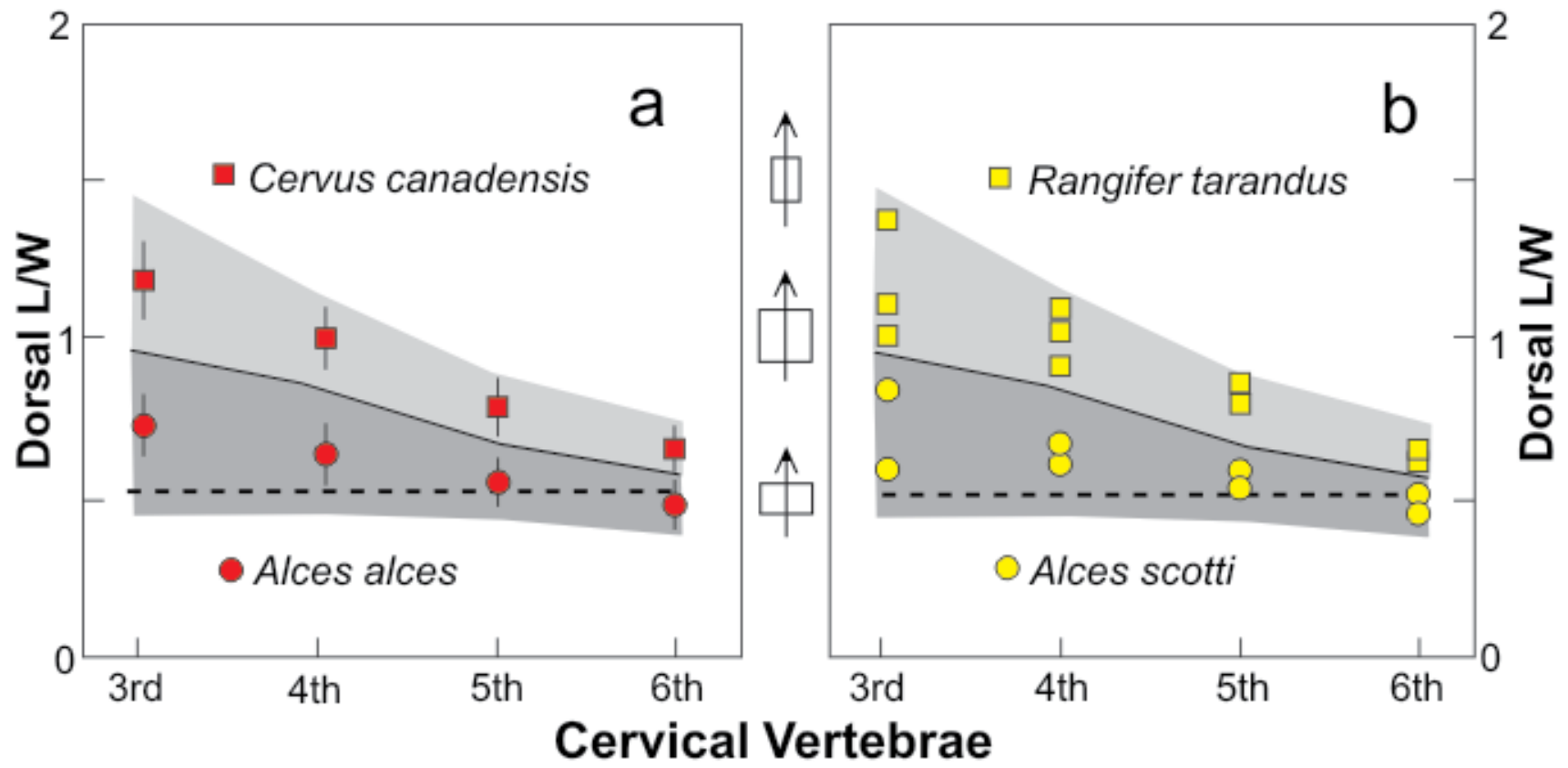

Fig. 6. Bone shape in dorsal view for large ice age cervids. Data are for CV3 to CV6 of animals listed in Table 1. Symbols between graphs give idealized bone shape for values on Y-axes. Arrows point toward animal's head. (a) Moose (dots) and elk (squares). Vertical bars give one standard deviation of respective data sets. Solid line separates moose domain (dark gray area) from elk domain (light gray area). All data for the two species fall within their respective domains. Dashed line shows dorsal shape ratio of Manasquan bone. (b) Caribou (squares) and elkmoose (dots). Elk domain, moose domain, and Manasquan bone value as in Fig. 6a.

Vertebral shape in dorsal view for $\mathrm{CV} 3$ to $\mathrm{CV} 6$ of the animals listed in Table 1 is given in Fig. 6. We did not measure CV2, $\mathrm{CV} 3$, or CV7 for the reasons discussed above. Data for elk (squares) and moose (dots) are given in Fig. 6a. Each symbol represents the average shape ratio (L/W) for a specific vertebra. One standard deviation is shown by the vertical bars. All data points for moose fall within the dark gray area whereas all data points for elk fall within the light gray area. The separation of the two data sets is complete. This suggests that the shape of the cervical vertebrae of these two species is indeed different. Elk have neck bones elongated in the axial direction relative to moose. Fig. $6 \mathrm{~b}$ shows data for elkmoose and caribou. Also plotted here are the elk and moose domains from Fig. 6a. The caribou data fall in the elk region. Elkmoose plot with moose. The dorsal length-width ratio for the Manasquan vertebra is 0.52 . This is represented by the dashed line in Figs. $6 \mathrm{a}$ and $6 \mathrm{~b}$. It too falls in the moose domain along with the elkmoose data. It seems reasonable to conclude from Fig. 6 that the shape of the Manasquan vertebra in dorsal perspective is consistent with the view that the bone derives from a member of the genus Alces.

\section{Which Moose?}

If the bone is from a species of Alces, then we need to decide between Alces alces, Alces scotti, and Alces latifrons. The data in Fig. 6, however, do not give a clear indication as to which of these species the Manasquan bone belongs. Likewise, the ten other cervical bone metrics we tested are also indecisive, primarily because of the paucity of elkmoose data upon which to base comparisons with Alces alces. However, the North American fossil record for the Late Pleistocene and early Holocene provides information more useful than bone shape characteristics for discriminating between Alces species. Alces scotti is known only from North America. Alces latifrons is primarily a Eurasian species, although a Beringian population, apparently confined to a Wisconsinan age ice-free refugium, occurs in northern Canada and Alaska. Alces latifrons is, however, unknown in New Jersey. Beringian Alces latifrons predates Alces scotti in North America and is surmised by Azzaroli (1985) to be ancestral to Alces scotti. Thus, Alces latifrons can be excluded as the source of the Manasquan bone. Alces alces also is thought to have derived from Alces latifrons at about the same time as Alces scotti, but in Asia rather than North America (Kahlke 1990) and independently of the origin of Alces scotti. Only in the early Holocene did Alces alces move into North America (Kahlke 1990), including New Jersey. Once in North America, Alces alces very quickly replaced Alces scotti. Thus, the known record of Alces in North America, together with our radiocarbon date for the Manasquan bone of $23530 \pm 170$ years BP, strongly suggests that the Manasquan bone is much too old to be identified with North American Alces alces. It is, however, consistent with the time range of Alces scotti as discussed by Churcher and Pinsof (1987) and Kahlke (1990). We suggest, therefore, that the Manasquan bone is most probably from Alces scotti. 


\section{Which Cervical Vertebra?}

The four posterior-most cervical vertebrae of modern Alces alces show directed changes in several characteristics (see Fig. 7). For example, the height of the neural spine relative to the body of the bone increases posteriorly with position in the neck, i.e., from CV3 to CV6. Unfortunately this parameter is of little value in the present context because the neural spine has been lost from the Manasquan vertebra (see Fig. 2). However, two other patterns of variation, more useful in placing the Manasquan vertebra in the neck of the animal from which it came, are apparent in Fig. 7. The first of these relates to the shape of the pleurapophyses. CV3 has flattened, paddle-like vanes forming the distal ends of the pleurapophyses. In CV4, these vanes have developed strong flexures and have become broadly convex posteriorly. In CV5 the two main axes of the distal pleurapophysis have separated to form two distinct, but closely approximated processes. In CV6 these processes are widely separated forming a keel-like ventral process and a lateral transverse process. The second useful pattern of variation involves the transverse foramina on either side of the centrum. The transverse foramina increase markedly in size relative to bone size backward along the neck. CV3 has small transverse foramina positioned close to the centrum, while the more posterior vertebrae have larger foramina that extend laterally away from the centrum. These two patterns are present in all of the moose and elkmoose specimens that we examined and would thus appear to be species-wide characters.

Although the Manasquan vertebra has endured significant bone loss due to post-mortem abrasion, Fig. 2 indicates that one can still assess its status with regard to these two characters. In Fig. 2 the left pleurapophysis and the distal end of the right pleurapophysis are seen to be missing, but it is nevertheless clear that, on the right side of the bone, there is no indication that the pleurapophysis has bifurcated into two separate processes. The base of the right pleurapophysis is wide and robust, as is the case in CV3 and to a lesser extent in CV4, as illustrated in Fig. 7. Thus, we infer that the Manasquan bone is either a CV3 or CV4. The transverse foramina in the Manasquan bone support this view also. They are filled with sediment and encrusted material and thus partly hidden, but the outer rim of the left transverse foramen is visible in Fig. 2a (arrow). The foramen is small and close to the centrum. It is what one sees in CV3 in Fig. 7. In addition, the left side of the bone does not flare out around the foramen as in the case of CV4, but rather runs straight down to the pleurapophysis as in CV3. Thus, we conclude that the Manasquan bone is most likely to be a CV3.

\section{ALCES SCOTTI FROM NEW JERSEY}

In addition to the Manasquan bone, the New Jersey fossil record has two nearly complete skeletons of Alces scotti, both of which were discovered in post-glacial bogs in the northern part of the state (Fig. 1). The first of these skeletons was described by Scott (1885) and was found in Mt. Hermon, Hope Township,
Warren County (see Fig. 1 for location). It is now deposited in the collection of Princeton University (PU 10468) and is on display at the New Jersey State Museum (NJSM), Trenton. Parris (1983) considered this skeleton to be the finest of this species in existence. The second skeleton was found in Columbia, Warren County (Fig. 1) and was described and radiocarbon dated by Harrington (1984). It is now in the Philadelphia Academy of Natural Sciences (ANSP 11286). Additional New Jersey discoveries of Alces scotti include: 1) a major portion of a skeleton found in Knowlton, Warren County (Fig. 1), now in the the Natural History and Science Museum, Blairstown, NJ (NJM 264) the American Museum of Natural History has an accurate plaster cast collection of this specimen (AMNH107678); 2) an antler fragment (NJSM12109) found along Big Brook in Marlboro Township, Monmouth County (Fig. 1); and 3) a right metacarpal bone(PU 16342), originally found by Whitmore et al. (1967) and figured and described by Gallagher et al. (1987) according to Whitmore et al. (1967), this specimen came from the floor of the Hudson Submarine Canyon off the New Jersey coast at a water depth of $160 \mathrm{~m}$ (Fig. 1).

\section{GEOLOGIC AGE OF ALCES SCOTTI}

Radiocarbon dates for unequivocal specimens of Alces scotti are few, and for the most part are from material recovered in the mid-Atlantic region of the United States. All such dates lie at the younger end of the time range for North American occurrences of Alces. Harrington (1984) reported an age of 11 $230 \pm 160$ years BP for a bone fragment taken from the Alces scotti skeleton from Columbia, New Jersey, while Buckley and Willis (1970) established an age of $10950 \pm 150$ years BP for an Alces scotti rib found near Middletown, New York. Dulian (1975) gave an age of $12420 \pm 180$ years BP for an antler fragment from Brayton, Iowa, which he referred to as Alces scotti. The radiocarbon date we report here for the Manasquan bone (23 530 \pm 170 years BP), makes this the oldest Alces scotti material yet found in North America, and confirms the prediction of many earlier researchers (e.g., Churcher and Pinsof 1987; Kahlke 1990) that the record of Alces scotti extends further back in time than the radiometric data then indicated.

\section{SEDIMENTOLOGY AND DEPOSITIONAL HISTORY OF THE MANASQUAN VERTEBRA}

Much of the continental shelf bordering the mid-Atlantic and New England regions of the United States and the Maritime Provinces of Canada is covered by thick relict sand and silt produced by sea-level rise associated with the waning of the Wisconsinan ice sheet (Whitmore et al. 1967). This sediment is, in effect, a transgressive lag deposit produced by the mixing of post-Wisconsinan sediment introduced by Holocene and modern rivers draining the adjacent land areas, and the exhumation, mobilization, and redeposition of Pleistocene and older continental-shelf sediment resulting 


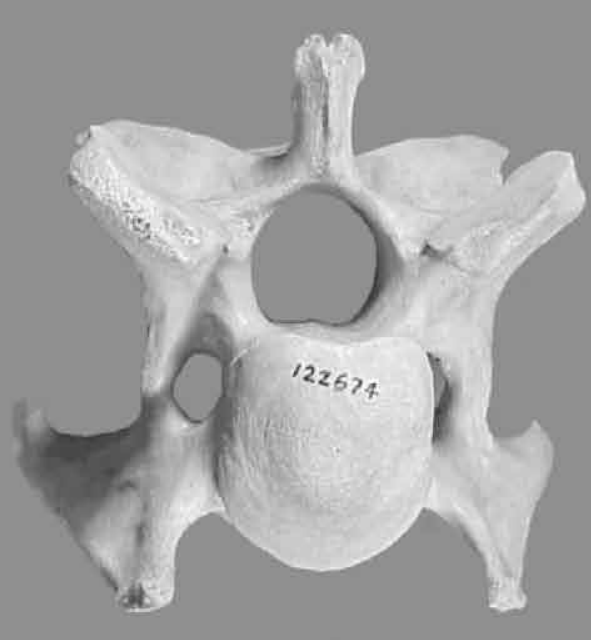

CV3

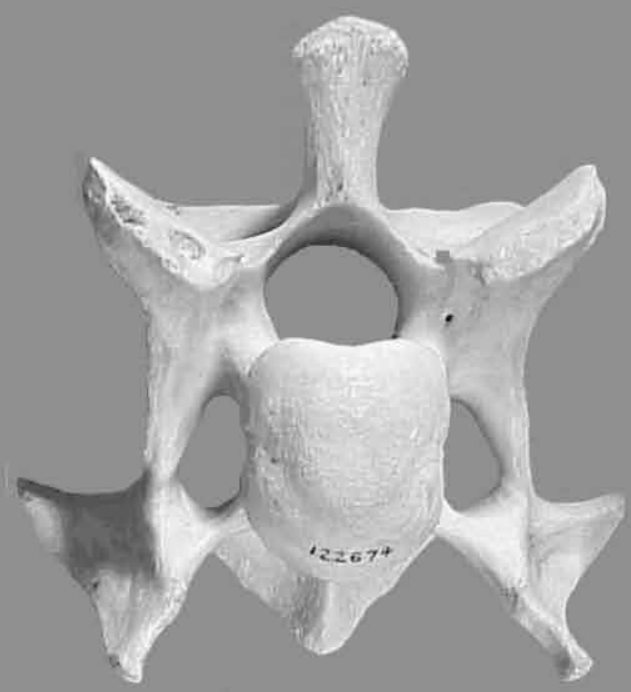

CV4

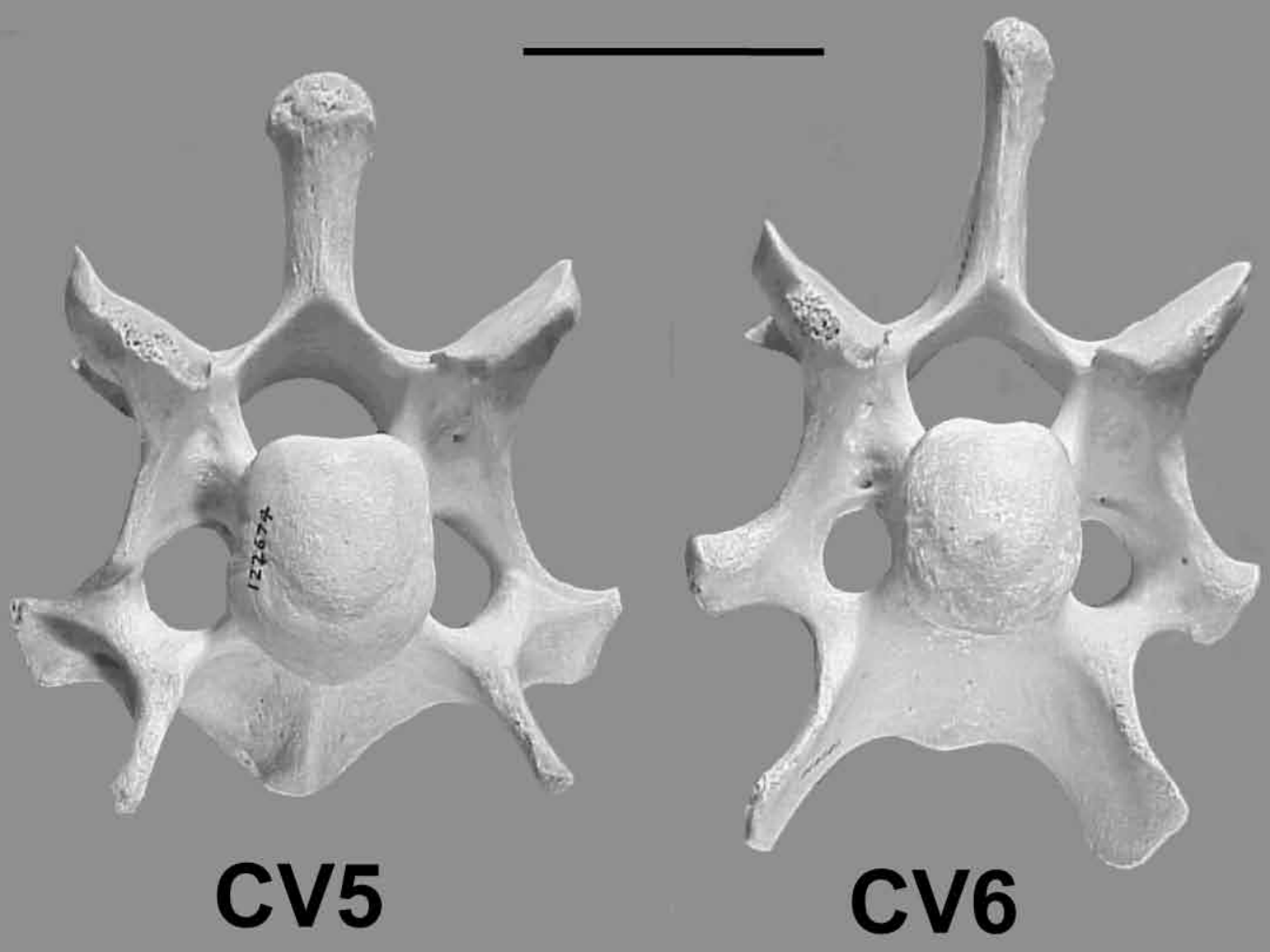

Fig. 7. Cervical vertebrae of a modern moose in anterior view (AMNH122674). Vertebrae arranged serially from top left to lower right with bone position in the neck indicated in the figure $(\mathrm{CV} 3=$ third cervical vertebrae, etc.). Scale bar $=5 \mathrm{~cm}$. 
from Holocene sea-level rise and storm activity. As might be expected with a transgressive lag deposit, fossils indicative of a wide range of geologic ages have been recovered from this sediment and include examples from the Holocene, Miocene and upper Cretaceous (Dall 1925; Uchupi 1964; Wigley 1966; Stanley et al. 1967; Stoffer et al. 1999). It would appear, therefore, that our cervical vertebra is another rare example of an older terrestrial fossil being mobilized and redeposited in this transgressive lag.

We postulate that the Manasquan bone reached the discovery site in one of two ways. First, the animal from which this bone came may have lived on the exposed part of the continental shelf when sea level was lower than today. After its death, when rising sea level submerged this part of the shelf, its remains were incorporated into the relict sand at or near the discovery site. This mode of preservation would have entailed little or no fluvial post-mortem transport of the remains. Alternatively, the animal could have been living landward of the present coastline, perhaps like those elkmoose recovered from the peat bogs of northern New Jersey. The Manasquan bone would then have been carried out onto the shelf by fluvial transport, probably when the shoreline was close to the position at which the bone was found. This would have been about 10000 to 12000 years ago, when the coastline approximated the present $50 \mathrm{~m}$ bathymetric contour (Wright et al. 2009). This was the interval in which the retreat of the Laurentide Ice Sheet northward of the Adirondack Uplands caused glacial Lake Iroquois in the Ontario Basin and glacial Lakes Albany and Vermont in the Hudson-Champlain Lowland to catastrophically drain southward though the Hudson Valley and out onto the New York-New Jersey coastal plain (Uchupi et al. 2001: Donnelly et al. 2005; Rayburn et al. 2005; Thieler et al. 2007). It is thus possible that the Manasquan bone was one of the objects carried seaward in such a glacial outburst flood. Such an extensive, and possibly violent, transport history would undoubtedly involve considerable physical degradation of transported objects. In view of the relatively intact condition of the specimen, this alternative scenario seems less likely than preservation with little or no transport.

\section{CONCLUSIONS}

Morphological analysis and the radiocarbon age (about 23 530 years BP) of a bone dredged from the continental shelf $40 \mathrm{~km}$ southeast of Manasquan, New Jersey, suggests that the specimen is the third cervical vertebra of an elkmoose, an extinct moose-like animal belonging to the species Alces scotti (Lydekker, 1898) and congeneric with of the modern moose, Alces alces (Linnaeus, 1758). The animal from which this bone derives was probably living in a tundra or taiga setting near the location on the now submerged coastal lowland where it was found. However, there is a possibility, albeit remote given the good condition of the specimen, that the bone came from an animal living landward of the modern shoreline and was carried to the discovery site postmortally by rivers or by catastrophic glacial outburst flooding.

\section{ACKNOWLEDGMENTS}

We thank David Parris and William Gallagher, New Jersey State Museum, who assisted in the identification of the cervical vertebra and provided access to PU 10648. Ted Daeschler, Academy of Natural Sciences of Philadelphia, assisted in our study of specimens in the ANSP collections. We are also grateful to Danielle Desroches, William Paterson University, Cecilia McHugh, Queens College, and Rob Fensome, Geological Survey of Canada (Atlantic), for their comments on an earlier version of this paper. Editorial assistance was provided by Lauren Smith and Marlayna Sosna, William Paterson University.

\section{REFERENCES}

Azzaroli, A. 1981. On the Quaternary and Recent cervid genera Alces, Cervalces, Libralces. Bolletino de Societie Paleontologie Italiano, 20, pp. 147-154.

Azzaroli, A. 1985. Taxonomy of Quaternary Alcini (Cervidae, Mammalia). Acta Zoologica Fennica, 170, pp. 179-180.

Bensley, B. A. 1913. A Cervalces antler from the Toronto Interglacial, Cervalces borealis sp. nov. University of Toronto Studies in Geology, 8, pp. 1-3.

Buckley, F. D., and Willis, E. H. 1970. Isotopes and radiocarbon measurements VIII. Radiocarbon, 12, pp. 87-129.

Churcher, C., and Pinsof, J. 1987. Variation in the antlers of North American Cervalces (Mammalia: Cervidae): review of new and previously recorded specimens. Journal of Vertebrate Paleontology, 7, pp. 373-397.

Dall, W. 1925. Tertiary fossils dredged off the northeastern coast of North America. The American Journal of Science, 10, pp. 213-218.

Donnelly, J.P., Driscoll, N.W., Uchupi, E., Keigwin, L.D., Schwab, W.C., Thieler, E.R., and Swift, S.A. 2005. Catastrophic meltwater discharge down the Hudson Valley: a potential trigger for the Intra-Allerød cold period. Geology, 33, pp. 89-92. doi:10.1130/G21043.1

Dulian, J. 1975. Paleoecology of the Brayton Local Biota, Late Wisconsinan of southwestern Iowa. Unpublished M.S. Thesis, University of Iowa, Iowa City, Iowa, USA, $50 \mathrm{p}$.

Frick, C. 1937. Horned ruminants of North America. Bulletin of the American Museum of Natural History, 69, pp. 1-699.

Gallagher, W., Parris, D., Grandstaff, B., and DeTample, C. 1989. Quaternary mammals from the continental shelf off New Jersey. The Mosasaur, 4, pp. 101-110.

Harlan, R. 1825. Fauna Americana: being a description of the mammaliferous animals inhabiting North America. Philadelphia, $1825.318 \mathrm{p}$.

Harrington, C. 1984. Quaternary marine and land mammals and their paleoenvironmental implications - some exam- 
ples from North America. Carnegie Museum of Natural History, Special Publication, No. 8, pp. 511-525.

Hay, O. P., 1913. Descriptions of two new species of ruminants from the Pleistocene of Iowa. Proceedings of the Biological Society of Washington, 26, pp. 5-8.

Kahlke, H. D., 1990. On the evolution, distribution and taxonomy of fossil elk/moose. Quartärpaläontologie, 8, pp. 83-106.

Linnaeus., K. 1758. Systema Naturae. 10th edition. Holmiae: Impensis Direct (Laurentii Salvii), Stockholm, 873 p.

Lydekker, R. 1898. The deer of all lands - history of the family Cervidae living and extinct. Rowland Ward, London, $329 \mathrm{p}$.

McDonald, J., and Ray, C. 1990. The extinct sloth, Megalonyx (Mammalia:Xenarthra), from the United States mid-Atlantic continental shelf. Proceedings of the Biological Society of Washington, 103, pp. 1-5.

McDonald, J., and Ray, C. 1993. Records of musk oxen from the Atlantic Coastal Plain of North America. The Mosasaur, 5, pp. 1-18.

Parris, D. 1983. New and revised records of Pleistocene mammals of New Jersey. The Mosasaur, 1, pp. 1-21.

Rayburn, J.A., Knuepfer, P.L.K., and Franzi, D.A., 2005. A series of large late Wisconsinan meltwater floods through the Champlain and Hudson valleys, New York State, USA. In Re-assessing the role of meltwater processes during Quaternary glaciations. Edited by T.G. Fisher and A.J. Russell. Quaternary Science Reviews, 24, pp. 2410-2419.

Scott, W. 1885. Cervalces americanus, a fossil moose or elk from the Quaternary of New Jersey. Proceedings of the Academy of Natural Sciences of Philadelphia, pp. 180-202.

Stanley, D. J., Swift, D. P., and Richards, H. G. 1967. Fossiliferous concretions on Georges Bank. Journal of Sedimentary Petrology, 37, pp. 1070-1083.
Stoffer, P. W., Messina, P., and Chamberlain, J. A., Jr. 1999. Fossiliferous concretions from New York Bight beaches: implications for late Pleistocene and Holocene coastal environments around Sandy Hook and western Long Island. Geological Society of New Jersey Annual Proceedings, 16, pp. 119-143.

Thieler, E. R., Butman, B., Schwab, W.C., Allison, M.A., Driscoll, N.W., Donnelly, J. P., and Uchupi, E. 2007. A catastrophic meltwater flood event and the formation of the Hudson Shelf Valley. Palaeogeography, Palaeoclimatology, Palaeoecology, 246, pp. 120-136. doi:10.1016/j.palaeo.2006.10.030

Uchupi, E. 1964. Unusual hauls From Georges Bank. Oceanus, 10 , pp. 20-22.

Uchupi, E., Driscoll, N., Ballard, R.D., and Bolmer, S.T., 2001. Drainage of late Wisconsin glacial lakes and the morphology and late Quaternary stratigraphy of the New Jersey-southern New England continental shelf and slope. Marine Geology, 172, pp. 117-145. doi:10.1016/S0025-3227(00)00106-7

Whitmore, F., Emery, K., Cooke, H., and Swift, D. 1967. Elephant teeth from the Atlantic continental shelf. Science, 156, pp. 1477-1481. doi:10.1126/science.156.3781.1477

Wigley, R. 1966. Rare fossils dredged off the Atlantic Coast. Commercial Fisheries Review. 28, pp. 28-32.

Wright, J.D., Sheridan, R.E., Miller, K.G., Uptegrove, J., Cramer, B.S., and Browning, J.V. 2009. Late Pleistocene sea level on the New Jersey Margin: implications to eustasy and deep-sea temperature. Global and Planetary Change, 66, pp. 93-99. doi:10.1016/j.gloplacha.2008.03.013

Editorial responsibility: Robert A. Fensome 